\title{
自然歴からみた小监精巣・精索水瘤に対する手術適応
}

\author{
宮崎医科大学医学部泌尿器科学教室（主任：長田幸夫教授） \\ 山口 孝則 永田 豊春 濱砂 良一 長田 幸夫
}

\section{INDICATION FOR SURGERY OF PEDIATRIC TESTICULAR AND FUNICULAR HYDROCELES IN VIEW OF NATURAL COURSE}

Takanori Yamaguchi, Toyoharu Nagata, Ryoichi Hamasuna and Yukio Osada Department of Urology, Miyazaki Medical College

(Director: Prof. Y. Osada M.D.)

(Purpose) The purpose of this study is to confirm the definite indication for surgery of pediatric testicular and funicular hydroceles in view of natural course.

(Methods) During the period from 1978 to 1994, we encountered 160 hydroceles in 149 pediatric patients. Patients ages ranged from 5 days after birth to 13 years and the mean follow-up periods was 4.7 years. We investigated the indication for surgery of pediatric hydroceles in six points of view: value of an aspiration of hydroceles, of what testicular or funicular or both, communication, size, age and testicular development.

(Results) Nevertheless, of 160 hydroceles, 66 (41\%) were performed an aspiration of hydroceles, the aspiration of hydrocele was ineffective in the majority of patients. Common hydroceles in neonates and infants required no specific treatment, as the majority of hydrocele resolve spontaneously, however surgical treatment was required for a communicating large hydrocele that had been often attacked by aspiration and appeared at older age. Funicular hydroceles were more difficult to spontaneous healing. Ipsilateral testis manifests a welldeveloped comparing control material.

(Conclusion) The indication for surgery of pediatric hydroceles were as follows: 1) hydroceles complicated by a inguinal hernia or cryptorchidism, 2) hydroceles appeared at older age and not resolved during 2 $\sim 3$ years over, 3) giant communicating funicular and testicular hydroceles present with an hindrance for daily life.

Key words: pediatric testicular or funicular hydroceles, natural course, indication for surgery

要旨：(目的）われわれは長期遠隔成績を調查しえた小児精巣・精索水瘤患児について自然歴を中心に検 討し, 本症の手術適応についての考察を行った.

(方法) 1978年から1994年までに当科外来を初診し，平均4.7年の長期にわたって遠隔成績を調査しえ た生後 5 日目から13歳までの患児149例160水瘤を対象にした. 手術適応については穿刺法による功罪, 水瘤の形態, 交通性, 大きさ，初診時年齢，精巣の発育の 6 つの観点からこれを検討した.

(結果) 160 水瘤のうち66水瘤（41\%）が第刺を受けていたが, 穿刺を受けた症例ほど要手術水瘤が増 え，穿刺治癒率はわずか $24 \%$ あ゙あっ，また穿刺で治癒する水瘤の大多数は非交通性であった。形態的 には精巣水瘤よりも精索水瘤の方が, 非交通性よりも交通性の方が, また水瘤が大きいほど, 年長児で 発生するほど手術を必要とする症例が多かった。 また自然治癒までの期間も水瘤が大きいほど, 年長児 で発生するほど期間を要した。精巣の大きさについては正常対象群と比較し, 精巣の発育は良好であっ た.

（結論）本症はきわめて自然治癒傾向の強い疾患であり，今回の検討から本症の手術適応については 
まず鼠径へルニア，停留精巣などの合併例，幼児期以降の発症で $2 \sim 3$ 年以上治癒傾向を示さない水瘤， 日常生活に支障をきたすような巨大交通性水瘤などが手術適応になると考えられた。

キーワード：小児精巣・精索水溜，自然歷，手術適応

\section{緒 言}

小児の精巣および精索水瘤は泌尿器科, 小児外科領 域における日常診療においてきわめて頻度の高い疾患 であり，本疾患によって外来を訪れる患児は少なくな い. 本症の発症は腹膜鞘状突起の閉鎖との関連性があ ることから幼少児に多く,しかも自然治癒傾向が強く, 疾患そのものが患児に影響を及ぼさないとの理論から 早期の手術の必要性は否定的である ${ }^{1)}$.しかし本症は こうした点から停留精巣や鼠径へルニアなどの類似し た疾患に比べ関心がきわめて少なく，またその研究も 著しく少ないことにより，その治療や処置法は各臨床 家によって非常にまちまちである。本症の治療に関し て, 現在もなお多くの臨床家が保存的処置の一環とし て穿刺法を多用していることは以前われわれが報告し た2゙がここうした研究の一環として，長期に遠隔成績を 調査しえた149例，160水瘤について自然歴を中心に検 討し，本症の手術適応をいかに考えるべきかについて の考察を行った。

\section{対象・方法}

1978年から1994年までに当科外来を初診し，遠隔成 績を調查しえた生後 5 日目から13歳 7 カ月までの患児 149例を対象にした。患側は右側87例，左側51例，両側 11例の計 160 水瘤であり, 臨床的に精巣固有鞘膜腔内に 水瘤が限局していると考えられる精巣水瘤は96水瘤, 鼠径部の腹膜鞘状突起腔内にも水瘤が存在していると 考えられる精索水瘤は64水瘤であった。なお初診時鼠 径ヘルニアならびに停留精巣を合併した症例は含んで いない.

各症例の経過観察期間は初診後 8 力月から 12 年の平 均 4.7 年であり,原則として外来通院にて保存的に経過 観察し，手術適応については，(1)穿刺法による功罪， (2)水瘤の形態，(3)水瘤の交通性，(4)水瘤の大きさ，(5) 初診時年齢, (6)精巣の発育の 6 つの観点からこれを検 討した。初診時母親からの十分な病歴聴取により水瘤 の大きさが一日のうちで変化したり，体位変換や圧迫 触診によって水瘤の大きさが変化するものを臨床的に 交通性水瘤とし，大きさの全く変化しないものを非交 通性水瘤とした。また初診時水瘤の大きさはつぎの 5 段階に分けた。すなわち， I 度 little finger head size (長径 $1.5 \mathrm{~cm}$ 末満)，II度 thumb finger head size (1.5 $\mathrm{cm}$ 以上 $3.0 \mathrm{~cm}$ 末満), III度 pigeon's egg size $(3.0 \mathrm{~cm}$ 以上 $4.5 \mathrm{~cm}$ 未満), IV度 walnut size $(4.5 \mathrm{~cm}$ 以上 6.0 $\mathrm{cm}$ 末満), $\mathrm{V}$ 度 hen's egg size $(6.0 \mathrm{~cm}$ 以上）に分類 し，V度を超える水瘤を巨大水瘤とした。初診時年齢 は新生児期 ( 1 力月末満), 乳児期 ( 1 力月以上 1 歳未 満), 幼児期 ( 1 歳以上 6 歳未満), 学童期 ( 6 歳以上) に分け，各年齢での水瘤の治癒状況との相関について 検討した。

また経過観察中に何ら治療を必要とせず水留が消失 し, 以降再発のないものを自然治癒水瘤とし, 穿刺す ることによって水瘤が消失し，以後再発のないものを 穿刺治癒水瘤とした。穿刺後再貯留し，その後経過を みているうちに水瘤の消失した例は自然治癒水瘤に含 めた。さらに，観察中に水瘤の増大あるいは頻回の貯 留再発例など 2 年以上にわたり自然治癒傾向のない 例，あるいはへルニアの出現をみた例に対しては入院 の上手術療法を施行し，これらを要手術水瘤とした。 なお，自然治癒率ならびに要手術率は母集団として各 水瘤に対する割合を，穿刺治癒率は穿刺した水瘤数に 対する治癒した水瘤数の割合とした。

さらに小児の水瘤を保存的に自然経過をみることで 精巣の発育に悪影響がないかどうか検討するため, 精 栄・精索水瘤61症例について患側の精巣容積を各年齢 別に正常対象群 (114精巣) との間で比較した。精巣容 積は主に orchiometer を用い，水瘤が大きく精巣を触 知できない例は超音波下に精巣容積を測定した。

\section{結果}

1）穿刺法の功罪

図 1 小児精巣・精索水溜の治癒状況

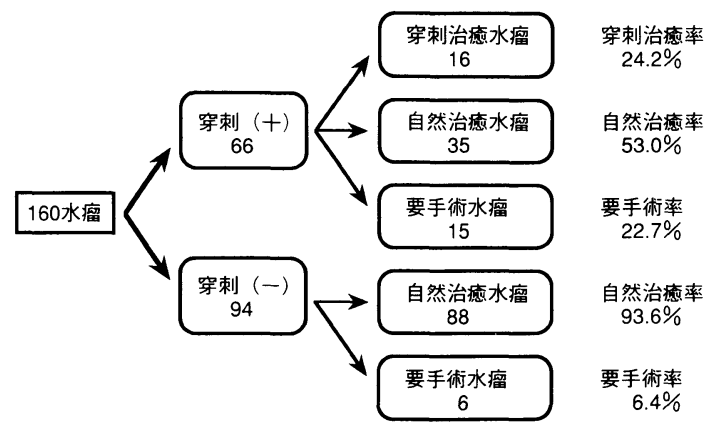


表 1 水瘤の形態と治癒状況

\begin{tabular}{|c|c|c|c|}
\hline & 精巣水瘤（96） & 精索水瘤（23） & 精巣·精索水瘤 (41) \\
\hline 自然治痖水瘤 & 78 & 17 & 28 \\
\hline $\begin{array}{l}\text { 穿刺治療水瘤 } \\
\text { (穿刺水䲣数) }\end{array}$ & $\begin{array}{c}10 \\
(38)\end{array}$ & $\begin{array}{c}2 \\
(8)\end{array}$ & $\begin{array}{c}4 \\
(20)\end{array}$ \\
\hline 要手術水瘤 & 8 & 4 & 9 \\
\hline 自然治㤫率（\%） & 81.3 & 73.9 & 68.3 \\
\hline 穿刺治瘾率（\%） & 26.3 & 25.0 & 20.0 \\
\hline 要手術率（\%） & 8.3 & 17.4 & 22.0 \\
\hline $\begin{array}{c}\text { 自然治聴までの期間（力月） } \\
\text { mean } \pm \text { S.D. }\end{array}$ & $17.8 \pm 8.3$ & $18.5 \pm 7.8$ & $21.1 \pm 9.2$ \\
\hline
\end{tabular}

160 水瘤の自然経過からみた治癒状況を図 1 に示し た。まず穿刺を受けたものが66水瘤あり，全体の 4 割 をしめ, うち 16 例は $1 \sim 3$ 回の穿刺により治癒し, 穿 刺治癒率は $24.2 \%$ あった. しかしこの16例中15例は 非交通性水瘤であり，交通性水瘤の穿刺治癒率は 31 例 中わずか 1 例の $3.2 \%$ であった。結局穿刺を受けたうち の76\%は再貯留し, 結果的に穿刺された水瘤では自然

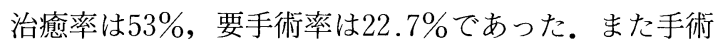
を要した 15 例中 4 例は穿刺後へルニアの出現を認めた ためであり, 残りの多くは穿刺後水瘤の増大のため手 術を必要とした症例であった。一方穿刺を受けなかっ た 94 水瘤中，自然治癒率は $93.6 \%$ によよ゙，手術を必 要としたのはわずか $6.4 \%$ であり,これらは日常生活に 支障となるような巨大水瘤であった。結果的に穿刺を 受けたものほど手術を必要とする水留が増え, しかも 穿刺で治癒する症例は穿刺例の $1 / 4$ 以下であった。

2）水溜の形態

水瘤の形態と治癒状況の相関をみると(表 1 ), 臨床 的に精巣固有鞘膜腔内に水瘤が限局していると考えら れる精巣水瘤が96水瘤に対し, 鼠径部の腹膜鞘状突起 内に限局する精索水瘤が23水瘤, 水瘤が大きく精巣固 有鞘膜を越えて精索まで及んでいると思われる混合型 が41水瘤であった。

各水瘤の治瘉状況を比較すると, 精巣水瘤の自然治 癒率が $81.3 \%$ に対し, 精索水瘤, 混合型ではそれぞれ $73.9 \%, 68.3 \%$ と低下し, 要手術率も精巣水瘤では $8.3 \%$ であが, 精索水留で $17.4 \%$, 混合型で $22.0 \%$ と 精索周囲に水瘤がおよぶにつれて要手術例が増え, 精
表 2 水溜の交通性と治瘾状況

\begin{tabular}{|c|c|c|}
\hline & $\begin{array}{l}\text { 交通性水瘤 } \\
(69)\end{array}$ & $\begin{array}{c}\text { 非交通性水瘤 } \\
(91)\end{array}$ \\
\hline 自然治癒水瘤 & 51 & 72 \\
\hline $\begin{array}{l}\text { 穿刺治癋水瘤 } \\
\text { (穿刺水溜) }\end{array}$ & $\begin{array}{c}1 \\
(31)\end{array}$ & $\begin{array}{l}15 \\
(35)\end{array}$ \\
\hline 要手術水瘤 & 17 & 4 \\
\hline 自然治癒率（\%） & 73.9 & 79.1 \\
\hline 穿刺治癒率（\%） & 3.2 & 42.9 \\
\hline 要手術率（\%） & 24.6 & 4.4 \\
\hline $\begin{array}{l}\text { 自然治癒までの期間 } \\
\text { (カ月) mean土S.D. }\end{array}$ & $19.2 \pm 8.9$ & $18.4 \pm 8.1$ \\
\hline
\end{tabular}

巣水瘤と混合型水瘤との間で有意差を認めた.しかし， 自然治癒までの期間は精巣水瘤で最も短い傾向には あったが, 水瘤の形態では有意差はなかった。

3）水瘤の交通性

臨床的に水瘤の大きさが変化する交通性水瘤は69水 瘤, 大きさの全く変化しない非交通性水溜は91水瘤で あった．両者間での治癒状況を比較した（表 2 ）が， 自然治癒率はそれぞれ $73.9 \%, 79.1 \%$ と有意差はない ものの, 穿刺治癒率は非交通性で $42.9 \%$ に対し, 交通 性ではわずか $3.2 \%$ であり，要手術率も非交通性では $4.4 \%$ であるが, 交通性では $24.6 \%$ と高率で, 両者間に 有意差を認めた。

4）水瘤の大きさ

初診時の水瘤の大きさは長径 $3.0 \sim 4.5 \mathrm{~cm}$ が最も多 
表 3 水瘤の大きさと治癒状況

\begin{tabular}{|c|c|c|c|c|c|}
\hline & I 度 $(6)$ & II度 (33) & III度 (58) & IV度 (43) & $\mathrm{V}$ 度 $(20)$ \\
\hline 自然治癒水瘤 & 6 & 28 & 45 & 32 & 12 \\
\hline $\begin{array}{l}\text { 穿刺治癒水瘤 } \\
\text { (穿刺水溜数) }\end{array}$ & $\begin{array}{c}0 \\
(1)\end{array}$ & $\begin{array}{c}4 \\
(10)\end{array}$ & $\begin{array}{c}8 \\
(25)\end{array}$ & $\begin{array}{c}3 \\
(17)\end{array}$ & $\begin{array}{c}1 \\
(13)\end{array}$ \\
\hline 要手術水瘤 & 0 & 1 & 5 & 8 & 7 \\
\hline 自然治癒率（\%） & 100 & 84.8 & 77.6 & 74.4 & 60.0 \\
\hline 穿刺治癒率（\%） & 0 & 40.0 & 32.0 & 17.6 & 7.7 \\
\hline 要手術率（\%） & 0 & 3.0 & 8.6 & 18.6 & 35.0 \\
\hline $\begin{array}{r}\text { 自然治癒までの期間 (カ月) } \\
\text { mean } \pm \text { S.D. }\end{array}$ & $7.4 \pm 3.1$ & $11.8 \pm 6.9$ & $19.5 \pm 8.7$ & $20.1 \pm 9.2$ & $29.8 \pm 11.4$ \\
\hline
\end{tabular}

I 度 : little finger head sized $(\mathrm{L}<1.5)$

$\mathrm{L}$ ：長径 $(\mathrm{cm})$

II 度 : thumb finger head sized $(1.5 \leqq \mathrm{~L}<3.0)$

III度 : pigeon's egg sized $(3.0 \leqq \mathrm{~L}<4.5)$

IV 度 : walnut sized $(4.5 \leqq \mathrm{~L}<6.0)$

$\mathrm{V}$ 度 : hen's egg sized $(6.0 \leqq \mathrm{~L})$

表 4 初診時年歯命と治癒状況

\begin{tabular}{|c|c|c|c|c|}
\hline & 新生児期 (14) & 乳児期 (46) & 幼児期 (74) & 学童期 (26) \\
\hline 自然治癒水瘤 & 14 & 44 & 53 & 12 \\
\hline $\begin{array}{l}\text { 穿刺治癒水瘤 } \\
\text { (穿刺水溜数) }\end{array}$ & $\begin{array}{c}0 \\
(0)\end{array}$ & $\begin{array}{l}1 \\
(9)\end{array}$ & $\begin{array}{c}8 \\
(38)\end{array}$ & $\begin{array}{c}7 \\
(19)\end{array}$ \\
\hline 要手術水瘤 & 0 & 1 & 13 & 7 \\
\hline 自然治癒率（\%） & 100 & 95.7 & 68.9 & 46.2 \\
\hline 穿刺治癒率（\%） & - & 11.1 & 21.1 & 36.8 \\
\hline 要手術率（\%） & 0 & 2.2 & 17.6 & 26.9 \\
\hline $\begin{array}{r}\text { 自然治癒までの期間（力月） } \\
\text { mean } \pm \text { S.D. }\end{array}$ & $5.2 \pm 2.8$ & $9.3 \pm 5.6$ & $21.8 \pm 9.5$ & $34.2 \pm 13.3$ \\
\hline
\end{tabular}

く, 最小は長径 $1.2 \mathrm{~cm}$, 最大は長径 $10 \mathrm{~cm}$ であった. 大 きさを 5 段階に分け，その治癒状況を比較したところ (表 3 ), 径 $1.5 \mathrm{~cm}$ 未満の I 度の水瘤は全例自然治癒 し，自然治癒率は水瘤が大きくなるほど低下し径 6.0 $\mathrm{cm}$ 以上の $\mathrm{V}$ 度の水瘤では自然治癒率が $60.0 \%$ と最も 低かった。また自然治癒までの期間も水瘤が大きくな るほど期間を要し，径 $6.0 \mathrm{~cm}$ 以上の巨大水留では自然 治癒まで約 30 力かかる結果であった。

一方穿刺は大きな水瘤ほど行われる傾向にあった が，穿刺治癒率は水瘤が大きくなるほど低下し，V度 の水瘤では穿刺で治癒したのは 13 例中 1 例の $7.7 \%$ で あった。結果的に手術を必要とした水瘤は水瘤の増大 とともに増加し，V度の巨大水瘤では $35.0 \%$ と最も高 率であった。

5）初診時年齢

初診時年齢と治癒状況について表 4 に示した．初診 時の年齢は幼児期が最も多く，以下乳児期，学童期の 順で乳幼児期を合わせると $75 \%$ をしめた。新生児期の
14水瘤は全例自然治癒し，この時期の水瘤の自然治癒 率が $100 \%$ であるのに対し, 年齢が増すほど自然治癒率 は低下し，しかも自然治癒まで期間を要する傾向であ り, 学童期の水瘤で自然治癒率 $46.2 \%$ と最も低く, 自 然治癒までの期間も平均 34.2 力 月であった。一方各年 齢における穿刺治癒率は, 新生児期に穿刺法を施行さ れた症例はなく，以降年齢とともに穿刺治癒率は増加 したが，逆に年齢が増すにつれて要手術率も増加し， 学童期では $26.9 \%$ が要手術例であった。

6）精巣の発育

小児精巣・精索水瘤の患側精巣容積について各年歯命 別の正常小児の精巣容積との比較を図 2 に示した. 各 年齢とも正常対象群と比較したところ差はなく, 精巣 の発育は良好であった。

\section{考 察}

小児の精巣・精索水瘤の発生機序については腹膜鞘 状突起の閉鎖異常がその根本にある31 5) ことは確か で，本疾患の成立の前提になるような腹膜鞘状突起の 
図 2 精巣容積の比較

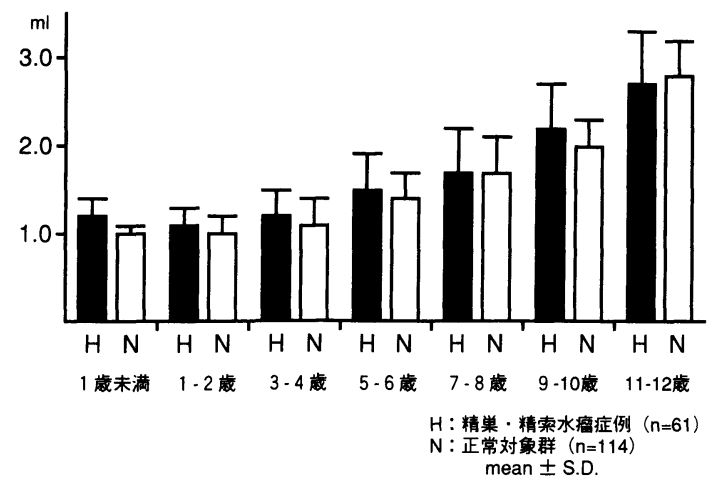

開存は生下時に $94 \% ， 1$ 歳でも57\%に認められる ${ }^{6)}$

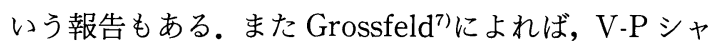
ント症例では非常に高率に精巣・精索水瘤の発生をみ ることから, 腹水の存在が水瘤の発生に影響するとし ており, 若山ら ${ }^{8)}$ の指摘するように, 水溜貯留液は腹膜 浸出液 (peritoneal fluid) であることも理解できる. このことは, 小児の本症の病因を考える上できわめて 重要な点であり, 成人とは違うことを念頭に入れてお く必要がある。こうした症例は後に鞘状突起の一部に 閉鎖がおき非交通性となる症例があるが，少なくとも 現実には小児の水瘤はすべての例が交通性と考えられ る ${ }^{9)}$. しかし, 臨床的には水瘤を圧迫しても形態に変化 がなく, 交通性水瘤特有の夕方活動時に大きく, 朝方 起床時には小さくなっているという日内変化が全くな い水瘤も存在し，これを今回臨床的に非交通性水瘤と した.しかし，臨床的に非交通性とした症例において も常に腹膜鞘状突起の開存を考慮しておかなければな らないのは当然である.

こうしたことから小児における水瘤穿刺は理論的に は全く無意味であると考えられるが，今もなお小児に 対し, 水瘤穿刺が行われていることは驚きに值する. われわれは以前本症の穿刺法の功罪について報告 し2)，小児に対する水瘤穿刺は決してみだりに行うべ きではなく, 穿刺が患児に与える精神的苦痛, 穿刺直 後の再貯留, 穿刺後の発熱, 血腫形成, ヘルニア発生 例をみるなどの少なくない合併症, さらにかえって自 然治癒を遅らせる原因となっていることなど, むしろ 悪影響と考えるべきであることを強調した. 今回の検 討でも交通性と非交通性水瘤の自然治癒率に有意差が ないにもかかわらず, 交通性水瘤で要手術率が増えて いるのは, 臨床的に明らかに交通性水瘤と考えられる
症例に安易に穿刺がなされている結果である。

本症の研究を初めて以降, 交通性水瘤を含め多くの 症例に対し穿刺法が行われてきたことは驚くばかりで あり, 以前報告した際には当科初診以前に他院で施行 されたものを中心に半数を超えており,川中ら ${ }^{10)}$ の 2,027 例のアンケート調查の中でも $62 \%$ が穿刺を受け たことがあると答えている.その後1990年以降の啓蒙 活動によってずいぶん穿刺例は減少してきているが, 実際今日でも小坚精巣・精索水瘤に対し約 $1 / 5$ の症例が なおも穿刺を受けているのが現状である.さらに一部 の臨床家においては穿刺の上ミノサイクリンの硬化療 法を行い，小児の精巣水瘤に対しても有効であると論 じる報告がある11)。こうした報告に対し筆者は異論を 唱えており ${ }^{12)}$, 小児の精巣水瘤については, 前述のごと く腹膜䩪状突起の開存の可能性を常に念頭にいれて, 化学的腹膜炎, 局所刺激による精索周囲脈管への侵襲, 精巣の血流障害など, 精巣の将来の発育に重篤な合併 症が決してあってはならないことをあらかじめ十分確 認されなければならないと考える。

一方，小児の精巣・精索水瘤を放置した際の精巣へ の悪影響については, 水瘤の温度の影響など精巣の組 織学的な検討が必要かもしれないが，こうした症例に 対する精巣生検などの検索は施行していない.今回は 精巣容積のみを各年代の正常小児と比較したが，正常 対象群と比較し精巣は正常に発育しており, 水瘤を放 置することによる精巣の発育に対する影響はまずない ものと考えている.

これらのことょり，小児精巣・精索水瘤の治療に対 しては待機的に自然経過をみる原則については問題な いと思われるが，本症の手術適応については報告者に よってさまざまである.松村ら ${ }^{13)}$ は, 15年間に外来を訪 れた 1,087 例もの精巣・精索水瘤についてへルニア合併 例を除き $36.9 \%$ に手術を施行し，1歳代 $49 \% ， 2$ 歳代 $48 \% ， 3$ 歳代 $54 \% ， 4$ 歳代 $70 \%$ と年齢とともに手術率 が増加するとしている。こうした幼児期の精巣・精索 水瘤の半数に手術が必要であるとは到底考えられな い.一方で川中ら ${ }^{10)}$ は，初期は50\%の手術率であった が，注意深い観察により $4 \%$ の手術率に低下したと報 告している，われわれの今回の検討でも要手術率は全 体の $13.1 \%$ をしめたが，特にここ 5 年間は $5 \%$ 以下の 低率で推移している。

今回の検討を通じて小児精巣・精索水瘤の形態, 交 通性, 大きさ, 初診時年齢からみた要手術水瘤の背景 について図 3 に示したが, 形態では精巣水瘤よりも精 
図 3 要手術水瘤の背景
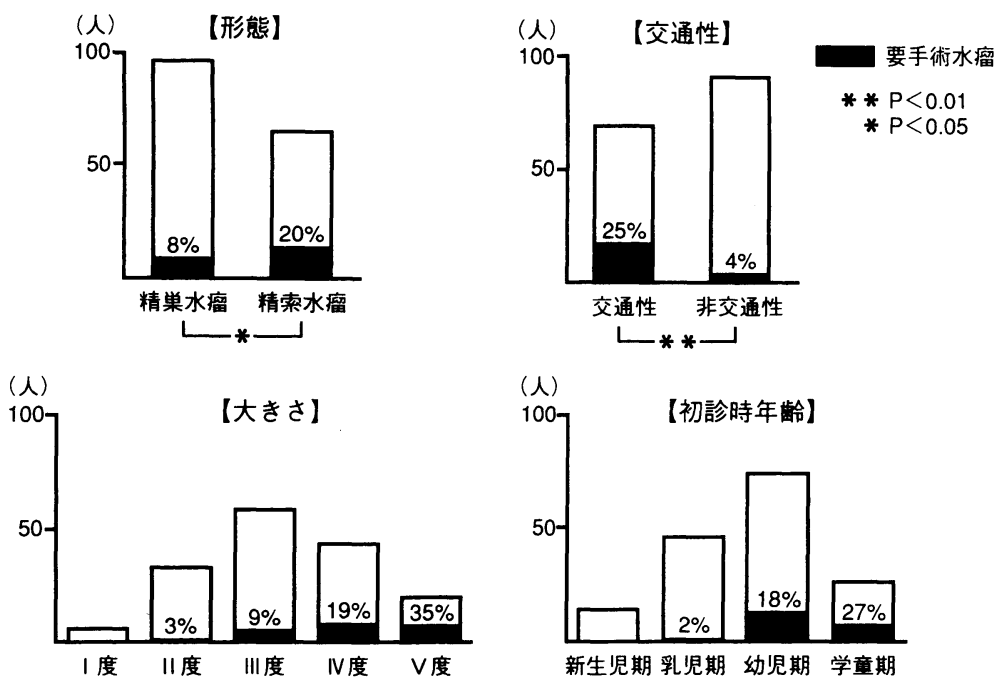

索水瘤が, 非交通性よりも交通性水瘤の方が有意差を もって要手術水瘤が増える結果であり，また水瘤が大 きいほど,さらに年長児で発生するほど自然治癒しに くい傾向にあるものと考えられる.ここでいう自然治 癒傾向のないものとはどのくらい待てばいいのかとい う疑問が生じるが，われわれの今回の検討から乳児期 まではほぼ 1 年以内に, 幼児期では約 2 年, 学童期で は約 3 年で自然治癒しており，幼児期以降の自然治癒 までの期間が平均25力月であることを考えれば，最低 $2 \sim 3$ 年は自然治癒に期待し, 待機的に経過をみる必 要があるものと考える。

回顧的にわれわれが手術に踏み切った症例をみる と, 穿刺によってヘルニア出現, 水瘤増大などの合併 症を引き起こした症例, 前述の自然治癒期間を越えて も軽快傾向を示さない日常生活に支障となるような大 きな水瘤であり，家族が患児の心理面から手術を強く 希望した症例であった。

われわれは今回の検討を通じ手術適応については以 下のごとく考えている. まず第一に鼠径へルニアや停 留精巣を合併した症例では手術を急ぐ必要があり, こ れらの合併症を有する水瘤. 第二に年長児, 少なくと も幼児期後半以降で， $2 \sim 3$ 年以上治癒傾向を示さな い水瘤. 第三に交通性で腹膜鞘状突起までおよぶ大き な水瘤は自然治癒までかなりの期間を要すことから, 日常生活に支障をきたし，患児の心理面に影響するよ うな巨大交通性水瘤などがその適応になるものと思わ れる。これらの 3 つの手術適応をあげたが，今回の検

討より本症はきわめて自然治癒傾向の強い疾患である ことが再認識され，手術適応の決定に関してはより慎 重な姿勢で取り組む必要があると考えられる。

本論文の要旨は，第32回日本小児外科学会総会で発表し た.

\section{文献}

1）秋山 洋：陰囊水腫根治術 (小児について). 消化 器外科, 10, 743-747, 1987.

2）山口孝則, 長田幸夫, 北田真一郎：自然歴からみた 小児陰囊・精索水瘤穿刺の功罪. 日小外会誌，27, 711-716, 1991.

3) Klauber, G.T. and Sant, G.R. : Disorders of the male external genitalia. Clinical Pediatric Urology. Kelalis, P.P., King, L.R., Belman, A.B., eds., p. 825-863, W.B. Saunders. Philadelphia, 1985.

4) Rajfer, J.: Congenital anomalies of the testis. Campbell's Urology. Walsh, P.C., Gittes, R.F., Perlmutter, A.D., et al. (eds.) p. 1947-1968, W. B. Saunders. Philadelphia, 1986.

5）梶本照穂，川中武司：腹膜鞘状突起の消長と鼠径 ヘルニアの発生. 小児外科, $18,289-295,1986$.

6) Allen, T.D.: Other intrascrotal abnormalities. Clinical Pediatric Urology. Keralis, P.P., King, L.R., Belmann, A.B., p. 662-664, W.B. Saunders. Philadelphia, 1976.

7) Grossfeld, L.: Inguinal hernia and ventriculoperitoneal shunt for hydrocephalus. Hernia, 2nd ed., p. 134-136, J.B. Lippincott, 1978.

8）若山待久, 北谷秀樹, 和田和久, 川中武司, 大浜和 
憲, 川口稜示, 宮本正俊, 中村紘一郎, 池田舜一, 橋本俱男, 梶本照穂, 浅野周二, 酒井義明: 小児陰 囊・精系水腫の成因に関する研究. 日小外会誌, 13, 577-585, 1977.

9) Rinker, J.R. and Allen, L. : A lymphatic defect in hydrocele. Am. Surg., 17, 681-686, 1951.

10）川中武司, 和田知久, 川口稜示, 梶本照穂, 中村俊 吾, 古田靖彦, 肥後正徳：小児の陰囊・精系水腫の 臨床的観察。外科治療，37，128-132，1977.
11）古賀 実，藤本博志，国富公人，高木 均，荒木 徹：陰囊水瘤に対する塩酸ミノサイクリン注入療 法. 臨泌, 47, 214-216, 1993.

12）山口孝則：交見室一小児陰囊水瘤に対しての塩酸 ミノサイクリン注入療法について. 臨泌, 47, 527 -528, 1993.

13）松村長生, 大塩猛人, 桐野有成 : 陰囊・精索水腫. 小児外科，23，301-304，1991.

(1996年1月19日受付，6月10日受理） 